(c) American Dairy Science Association, 2006.

\title{
Effect of Feeding Frequency of a Total Mixed Ration on the Performance of High-Yielding Dairy Cows
}

\author{
P. Mäntysaari, ${ }^{1}$ H. Khalili, and J. Sariola \\ MTT, Agrifood Research Finland, Animal Production Research, FIN-31600 Jokioinen, Finland
}

\begin{abstract}
Forty Finnish Ayrshire cows, 16 primiparous and 24 multiparous, were randomly assigned to 1 of 2 treatments (FF1 or FF5). Total mixed ration (TMR) was fed once a day on the FF1 treatment and 5 times a day on the FF5 treatment. The experiment began at calving and continued to wk 28 of lactation. The TMR consisted of a grass silage and concentrate mix. The amount of concentrate in the TMR was $51 \%$ on a DM basis. The feeding frequency had no effect on milk or energy-corrected milk yields or on milk composition. The average energy-corrected milk yield was $32.8 \mathrm{~kg} / \mathrm{d}$ on the FF1 treatment and $32.5 \mathrm{~kg} / \mathrm{d}$ on the FF5 treatment. The less frequent feeding increased the dry matter intake (DMI) of cows. The average DMI during the experiment was $20.9 \mathrm{~kg} / \mathrm{d}$ on the FF1 treatment and $19.9 \mathrm{~kg} / \mathrm{d}$ on the FF5 treatment. The difference in DMI was due to the differences in DMI of the mature cows. Energy and protein conversion tended to be lower with feeding once a day compared with feeding 5 times a day. The cows' feeding behavior was also observed. Cows fed 5 times a day tended to eat quite evenly after each delivery, whereas on the FF1 treatment there were 2 clear feeding peaks in the evening after the feed delivery. The time spent eating during the observation period was longer on FF5 than on FF1. The cows fed once a day spent more time lying than the cows fed 5 times a day. Based on the observations of feeding behavior, feeding a TMR 5 times a day seemed to be too frequent based on the increased restlessness and decreased lying time of the cows.
\end{abstract}

Key words: feeding frequency, dairy cow, total mixed ration, milk production

\section{INTRODUCTION}

In Finland it is common practice to feed dairy cows a TMR once or twice a day to keep the labor cost to a minimum. However, feeding robots are available,

Received March 21, 2006.

Accepted May 25, 2006.

${ }^{1}$ Corresponding author: paivi.mantysaari@mtt.fi allowing more frequent feeding with a limited labor requirement. These robots are quite an expensive investment, although the building cost of new cow barns can be reduced, because robots require less room than a tractor-pulled mixer wagon. The effect of feeding frequency on the performance of dairy cows has been examined in many studies. In a review of 35 experiments, Gibson (1984) concluded that increasing the feeding frequency of dairy cows to 4 or more times a day, compared with once or twice a day, increased the milk fat percentage by an average of $7.3 \%$ and increased milk production by $2.7 \%$. In the studies reviewed, however, the feeding strategies varied from feeding concentrates separate from forages to feeding complete diets, so the results are not directly applicable to today's high-producing cows fed TMR.

More recent results with TMR feeding have been variable. In the studies by Shabi et al. (1999) and Le Liboux and Peyraud (1999), increasing the number of feedings from 1 to 2 , to 4 to 6 increased the DMI of the TMR, but had no effect on milk production. Contrary to these results, in the study by Phillips and Rind (2001), the DMI and milk yield were higher with feeding once a day compared with 4 times a day. Phillips and Rind (2001) concluded that frequent feeding disturbed the cows and reduced milk production. In their study the cows were housed in a free-stall barn, whereas in the studies by Shabi et al. (1999) and Le Liboux and Peyraud (1999), the cows were stanchioned. The housing type can change the feeding behavior (Albright and Arave, 1997) and therefore alter the effect of feeding frequency on the cows' performance. The feeding behavior of high-yielding cows has also been shown to differ from the behavior of low producers (Grant and Albright, 1995). Thus, the milk-producing capacity of the cow can influence its response to different feeding frequencies. This experiment was conducted during the indoor period to examine how feeding frequency of a TMR might affect the feed intake, milk production, and feeding behavior of high-yielding cows housed in a free-stall barn.

\section{MATERIALS AND METHODS}

\section{Animals and Experimental Design}

Forty Finnish Ayrshire cows, 16 primiparous and 24 multiparous, were blocked by projected date of parturi- 
Table 1. The chemical composition and estimated feed values of the ingredients and TMR (mean \pm SD)

\begin{tabular}{|c|c|c|c|}
\hline Item & Grass silage & Concentrate $\operatorname{mix}^{1}$ & TMR \\
\hline \multicolumn{4}{|l|}{ Chemical composition } \\
\hline $\mathrm{DM}, \%$ & $25.2 \pm 2.6$ & $88.3 \pm 0.6$ & $39.6 \pm 3.4$ \\
\hline \multicolumn{4}{|l|}{ In DM, \% } \\
\hline Ash & $7.5 \pm 0.6$ & $6.8 \pm 0.4$ & $7.1 \pm 0.3$ \\
\hline $\mathrm{CP}$ & $14.8 \pm 0.6$ & $19.1 \pm 0.7$ & $17.0 \pm 0.4$ \\
\hline Ether extract & $\mathrm{ND}^{2}$ & $5.3 \pm 0.4$ & $4.7 \pm 0.1$ \\
\hline NDF & $51.2 \pm 4.4$ & $22.7 \pm 1.6$ & $36.9 \pm 2.1$ \\
\hline Starch & ND & $35.2 \pm 3.3$ & $18.3 \pm 1.7$ \\
\hline Digestible OM & $70.6 \pm 1.7$ & ND & ND \\
\hline Water-soluble carbohydrates & $5.7 \pm 1.9$ & & \\
\hline Lactic acid & $7.3 \pm 1.3$ & & \\
\hline Acetic acid & $2.2 \pm 0.5$ & & \\
\hline Butyric acid & $0.02 \pm 0.02$ & & \\
\hline $\mathrm{pH}$ & $3.97 \pm 0.15$ & & \\
\hline Ammonia-N, g/kg of $\mathrm{N}$ & $73 \pm 6.7$ & & \\
\hline Soluble $\mathrm{N}, \mathrm{g} / \mathrm{kg}$ of $\mathrm{N}$ & $571 \pm 70.6$ & & \\
\hline \multicolumn{4}{|l|}{ Feed values in DM } \\
\hline $\mathrm{ME},{ }^{3} \mathrm{MJ} / \mathrm{kg}$ & $11.3 \pm 0.3$ & $12.5 \pm 0.06$ & $11.9 \pm 0.09$ \\
\hline $\mathrm{AAT},{ }^{4} \mathrm{~g} / \mathrm{kg}$ & $86 \pm 1.6$ & $116 \pm 1.1$ & $101 \pm 0.9$ \\
\hline $\mathrm{PBV}^{5} \mathrm{~g} / \mathrm{kg}$ & $1 \pm 6.3$ & $6 \pm 5.6$ & $4 \pm 3.3$ \\
\hline \multicolumn{4}{|c|}{$\begin{array}{l}{ }^{1} \mathrm{~A} \text { mix }(\% \text { in } \mathrm{DM}) \text { of barley }(60.6) \text {, rapeseed meal (27.0), molassed sugar beet pulp (10.0), and mineral } \\
\text { and vitamin mix (2.4). }\end{array}$} \\
\hline \multicolumn{4}{|l|}{${ }^{2}$ Not determined. } \\
\hline \multicolumn{4}{|c|}{${ }^{3}$ Metabolizable energy (MAFF, 1975, 1984). } \\
\hline \multicolumn{4}{|c|}{${ }^{4}$ Amino acids absorbed from the small intestine (MTT, 2004). } \\
\hline 5Dratoin bolone in the rum & & & \\
\hline
\end{tabular}

tion and parity (primiparous or multiparous) and randomly assigned to 1 of 2 treatments (FF1 or FF5) differing in feeding frequency. In the FF1 treatment the TMR was fed once a day, and in the FF5 treatment it was fed 5 times a day. The experiment began at calving and continued to wk 28 of lactation. The average age and weight after calving were $24.5 \mathrm{mo}$ and $586 \mathrm{~kg}$ for the primiparous cows, and $47.9 \mathrm{mo}$ and $636 \mathrm{~kg}$ for the multiparous cows.

\section{Feeds, Feeding, and Housing}

All cows were fed the same TMR, which consisted of a grass silage and concentrate mix (Table 1). The amount of concentrate in the TMR was $51 \%$ on a DM basis. The grass silage used was prepared from primary-cut timothy (Phleum pratense) and meadow fescue (Festuca pratensis) sward wilted for 1 to $2 \mathrm{~h}$. A formic acid-based additive (5 L/t) was used at ensiling. The concentrate mix contained, in DM (\%), barley (60.6), rapeseed meal (27.0), molassed sugar beet pulp (10.0), and mineral and vitamin mix (2.4). The mineral and vitamin mix (Suomen Rehu Ltd., Helsinki, Finland) contained (g/kg) calcium (210), phosphorus (2), magnesium (100), sodium (100), selenium (0.02), vitamin A (13,000 IU/kg), vitamin D (81,000 IU/kg), and vitamin $\mathrm{E}(470 \mathrm{mg} / \mathrm{kg})$.

The cows were housed in a 2-compartment free-stall barn. Cows on different treatments were placed in dif- ferent compartments, which were separated by a milking parlor. Cows in different compartments were not able to see each other; therefore, the more frequent feeding of the FF5 group did not disturb the cows in the FF1 group. The cows were fitted with transponder collars that allowed identification in the milking parlor and feeding place. Each cow had an individual feeding place with free access to the TMR through computerized gates (RIC Access Doors; Insentec, Marknesse, The Netherlands). The TMR was mixed in a mixer wagon (Junkkari Ltd., Ylihärmä, Finland), and the feeding was carried out by a feeding robot (TR Feeding Robot; Pellonpaja Ltd., Ylihärmä, Finland). In the FF1 treatment, feeding took place at $1600 \mathrm{~h}$ and in the FF5 treatment at $0800,1320,1430,1800$, and $1940 \mathrm{~h}$. The gaps between feedings on the FF5 treatment were not uniform because of the feeding schedule of the other animals. To ensure ad libitum feeding, at least $5 \%$ daily refusals were required.

\section{Measurements, Sampling, and Analysis}

The amount of TMR offered was recorded automatically each day and TMR intakes were measured by recording the orts with an accuracy of $0.5 \mathrm{~kg}$ (fresh weight). A sample of the grass silage was taken twice a week. The subsamples were combined to give a 2wk sample for analysis. Samples were stored at $-20^{\circ} \mathrm{C}$. Thawed samples were analyzed for DM, ash, CP, NDF, 
quality of silage fermentation, and in vitro OM digestibility. The silage DM was corrected for the loss of volatiles according to Huida et al. (1986). The OM of the feeds was determined by ashing at $600^{\circ} \mathrm{C}$ for $18 \mathrm{~h}$. Neutral detergent fiber was analyzed according to Van Soest et al. (1991) using sodium sulfite in a NDF-detergent solution. Crude protein content was analyzed using a Dumas-type N analyzer (Leco FP-428 nitrogen analyzer; Leco Corporation, St. Joseph, MI). The in vitro $\mathrm{OM}$ digestibility of the silages was determined using a cellulose-based (Onazuka R-10; Yakult Honsha Ltd, Tokyo, Japan) method (Friedel, 1990). The silage was also analyzed for VFA (Huhtanen et al., 1998), lactic acid (Haacker et al., 1983), water-soluble carbohydrates (Somogyi, 1945), and ammonia N (McCullough, 1967). Concentrate samples were collected once a week and were combined to give a 4 -wk sample for analysis. The concentrate samples were analyzed for DM, ash, $\mathrm{CP}$, ether extract, NDF, and starch. Dry matter was determined by drying at $105^{\circ} \mathrm{C}$ for $20 \mathrm{~h}$. Starch was analyzed according to McCleary et al. (1994). Ether extract in the concentrates was determined after acid ( $\mathrm{HCl})$ hydrolysis according to the method of AOAC (1990).

Cows on the FF1 treatment were milked at 0630 and $1600 \mathrm{~h}$, and cows on the FF5 treatment were milked at 0730 and $1645 \mathrm{~h}$ in a $2 \times 6$ auto-tandem milking parlor. The milk yield was weighed and recorded automatically during each milking. Milk samples for milk protein, fat, and lactose analyses were collected every 2 wk from 2 consecutive milkings. The analyses were done using a MilkoScan 605 analyzer (Foss Electric, Hillerød, Denmark). Constituent concentrations were calculated as a weighted mean according to milk yield. Milk samples for milk urea analysis were collected every fourth week from 2 consecutive milkings of 7 cows per treatment and were pooled according to milk yield. The milk urea concentration was measured as ammonia following urease hydrolysis (McCullough, 1967).

The live weight of each cow was recorded automatically after each milking. The BCS were measured on a scale of 1 to 5 ( $1=$ skinny to $5=$ very fat $)$ with intervals of 0.25 as described by Lowman et al. (1976). The BCS were recorded at calving and every second week thereafter.

The behavior of the cows was observed for $15 \mathrm{~h}$ a day (0600 to $2100 \mathrm{~h}$ ) with 3 replicates. This made a total of $45 \mathrm{~h}$ of observation time per treatment. A day's observation was done in three 5 -h periods $(0600$ to $1100 \mathrm{~h}, 1100$ to $1600 \mathrm{~h}$, and 1600 to $2100 \mathrm{~h}$ ). The observation time covered the time when the TMR was delivered to the cows. During observation, the cows were identified by large numbers painted on their sides. A cow's behavior was classified and recorded on a handheld computer
(Psion Workabout; Psion PLC, London, UK) every 5 min using the following categories: eating, lying, standing, lying and ruminating, standing and ruminating. The time spent at milking was also recorded.

\section{Calculation and Statistical Analysis}

The ME content of the silage was based on the content of digestible $\mathrm{OM}$ in the $\mathrm{DM}(16 \mathrm{MJ} / \mathrm{kg})$. The $\mathrm{ME}$ content of the concentrates was calculated according to the Ministry of Agriculture, Fisheries and Food (MAFF, 1975, 1984). The digestibility coefficients of the nutrients in the concentrates were taken from the Finnish feed tables (MTT, 2004). The AA absorbed from the small intestine were calculated according to the Finnish feed tables (MTT, 2004). The energy and nutrient contents of the TMR were calculated from the values for grass silage and concentrate based on the proportion of each component in the TMR.

Two cows on the FF1 treatment were removed from the experiment because of mastitis and premature calving. Their data were excluded. Individual weekly averages were calculated from the daily intake, production, and BW measurements. The weekly average intake and production data were analyzed using the MIXED procedure of SAS (Littell et al., 1996). The REML method was used to estimate the variance component, and the type of within-subject covariance matrix used was firstorder autoregressive [AR(1)]. The model used was

$$
\begin{gathered}
\mathrm{y}_{\mathrm{ijklmn}}=\mu+\mathrm{FF}_{\mathrm{i}}+\mathrm{b}_{\mathrm{I}} \mathrm{I}_{\mathrm{j}}+\mathrm{P}_{\mathrm{k}}+\mathrm{S}_{\mathrm{ijkl}} \\
+\mathrm{W}_{\mathrm{m}}+(\mathrm{W} \times \mathrm{FF})_{\mathrm{mi}}+\mathrm{e}_{\mathrm{ijk} \mathrm{k}},
\end{gathered}
$$

where $\mathrm{FF}_{\mathrm{i}}$ represents the feeding strategy (feeding frequency 1 or 5 times a day); $b_{\text {I }}$ is the linear effect of the pedigree index $\left(\mathrm{I}_{\mathrm{j}}\right)$ of the cow appropriate for milk yield, fat, or protein content or yield; $\mathrm{P}_{\mathrm{k}}$ is parity; $\mathrm{S}_{\mathrm{ijkl}}$ is the random effect for the experimental cow; and $\mathrm{W}_{\mathrm{m}}$ is the week of lactation. Weekly average BW data and biweekly BCS were also analyzed using the model (Equation 1) without the effect of $b_{I} I_{1}$ and, in the case of BCS, with the exception that $\mathrm{W}_{\mathrm{m}}$ represented a 2 -wk period. The results were calculated and tested from the whole data set but also from separate data sets for the primiparous and multiparous cows. The behavioral data were also analyzed with the MIXED procedure of SAS (Littell et al., 1996). The REML method was used to estimate the variance component, and the type of within-subject covariance matrix used was unstructured [UN]. The model used included the treatment and observation period. In statistical analysis, significance was declared when $P<0.05(* P<0.05 ; * * P<0.01 ; * * * P<0.001)$. A tendency was declared when $P<0.10$. 
Table 2. Feed and nutrient intake (least-squares means) of the cows fed once or 5 times a day ${ }^{1}$

\begin{tabular}{lccll}
\hline $\begin{array}{l}\text { Dependent intake } \\
\text { variable }\end{array}$ & Treatment & Treatment & SEM & Significance \\
\hline $\mathrm{DM}, \mathrm{kg} / \mathrm{d}$ & FF5 & 19.9 & 0.28 & $*$ \\
$\mathrm{CP}, \mathrm{kg} / \mathrm{d}$ & 20.9 & 3.37 & 0.047 & $*$ \\
Ether extract, kg/d & 3.54 & 0.92 & 0.012 & $*$ \\
Starch, kg/d & 0.97 & 3.71 & 0.054 & $\dagger$ \\
$\mathrm{NDF}, \mathrm{kg} / \mathrm{d}$ & 3.85 & 7.45 & 0.107 & $\dagger$ \\
$\mathrm{ME},{ }^{2} \mathrm{MJ} / \mathrm{d}$ & 7.75 & 237 & 3.4 & $*$ \\
$\mathrm{AAT},{ }^{3} \mathrm{~kg} / \mathrm{d}$ & 249 & 2.01 & 0.029 & $*$ \\
\hline
\end{tabular}

${ }^{1}$ On the FF1 treatment, the TMR was fed once a day, and on the FF5 treatment, it was fed 5 times a day.

${ }^{2}$ Metabolizable energy (MAFF, 1975, 1984).

${ }^{3}$ Amino acids absorbed from the small intestine (MTT, 2004).

$\dagger P<0.10 ; * P<0.05$.

\section{RESULTS}

\section{Feeds and Feed Intake}

The chemical composition and calculated feed values of the ingredients and TMR are presented in Table 1. The concentrate mix had $190 \mathrm{~g}$ of CP in DM and its $\mathrm{ME}$ energy content was $12.5 \mathrm{MJ} / \mathrm{kg}$. The grass silage used had $706 \mathrm{~g}$ of in vitro digestible OM per kilogram of DM and the CP content was $148 \mathrm{~g} / \mathrm{kg}$ of DM. The fermentation characteristics of the grass silage were good (Table 1). The DM content of the TMR ranged from 35.4 to $46.3 \%$ (Table 1). The average energy (ME) and CP contents of the TMR were $11.9 \mathrm{MJ} / \mathrm{kg}$ of DM and $170 \mathrm{~g} / \mathrm{kg}$ of DM, respectively. The study was conducted in the winter so that secondary fermentation of the TMR in the feed bunk was not a concern.

The feed intake data for the cows are presented in Table 2. The average DMI of all the cows on the FF1 treatment was $20.9 \mathrm{~kg} / \mathrm{d}$ and on the FF5 treatment was $19.9 \mathrm{~kg} / \mathrm{d}(P<0.05)$. When parities were analyzed separately, no effect of feeding frequency on the DMI of the primiparous cows (18.7 vs. $18.1 \mathrm{~kg} \mathrm{DM} / \mathrm{d} ; P>$ 0.05 ) was found, whereas the multiparous cows fed once a day ate $1.5 \mathrm{~kg} / \mathrm{d}$ more DM (23.1 vs. $21.6 \mathrm{~kg} \mathrm{DM} / \mathrm{d}$; $P$ $<0.05)$ than the multiparous cows fed 5 times a day. Changes in DMI over time for primiparous and multiparous cows are shown in Figure 1. During the first weeks of lactation, the primiparous cows on the FF1 treatment ate more than the cows on the FF5 treatment, whereas with older cows no difference in the feed intake during the first weeks was observed. Instead, after the seventh week of lactation, the multiparous cows on the FF1 treatment ate more than the cows on the FF5 treatment. However, the interaction between lactation week and treatment on the feed intake was not significant.

The energy and nutrient intakes of the cows on the different treatments are shown in Table 2. Because the cows on both treatments were fed the same TMR, the differences in energy and nutrient intakes followed the differences in DMI.

\section{Milk Production and Composition}

The production data for the cows are presented in Table 3. The frequency of feeding had no effect on milk and ECM yields. The average ECM yield was 32.8 and
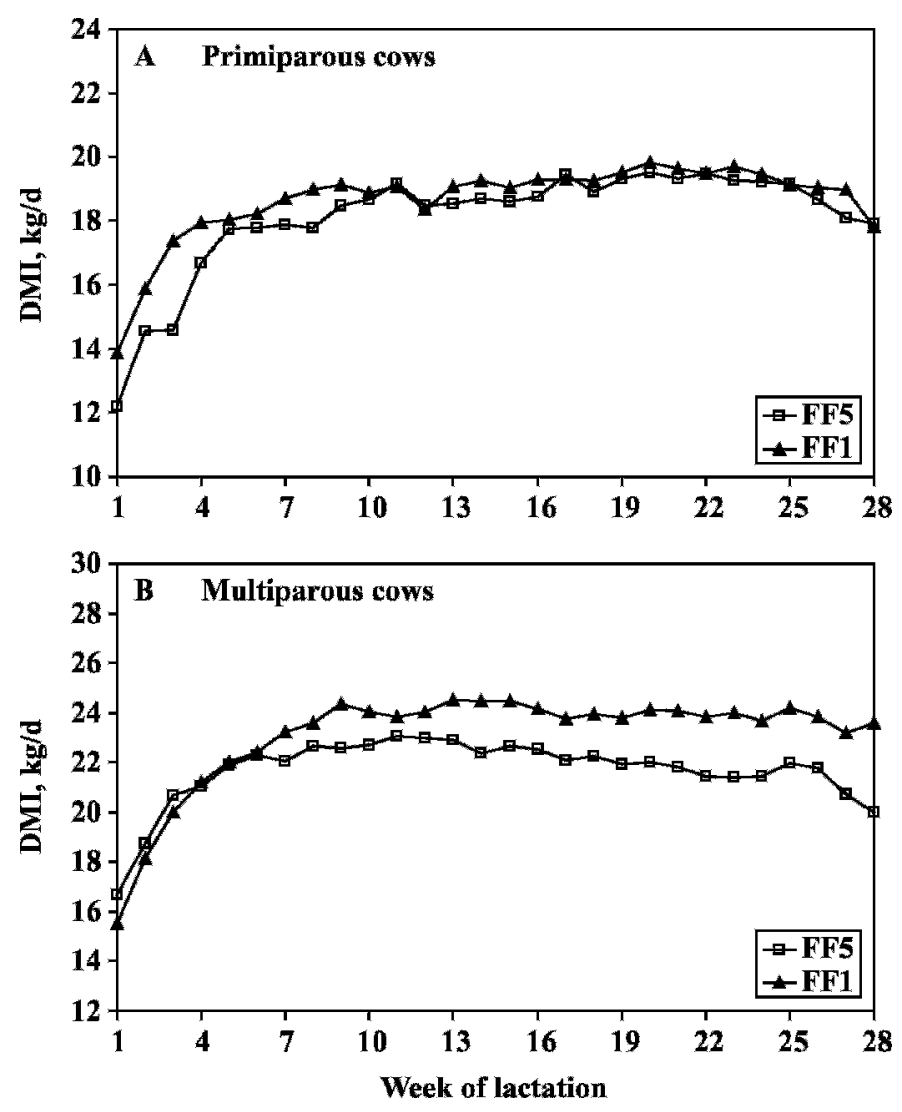

Figure 1. Dry matter intake of primiparous (A) and multiparous (B) cows fed a TMR once (FF1) or 5 (FF5) times a day. 
Table 3. Milk production and composition as well as energy and protein conversion of cows fed once or 5 times a day ${ }^{1}$

\begin{tabular}{|c|c|c|c|c|}
\hline $\begin{array}{l}\text { Dependent production } \\
\text { variable }\end{array}$ & $\begin{array}{l}\text { Treatment } \\
\text { FF1 }\end{array}$ & $\begin{array}{l}\text { Treatment } \\
\text { FF5 }\end{array}$ & SEM & Significance \\
\hline Milk, kg/d & 31.8 & 31.8 & 0.92 & NS \\
\hline $\mathrm{ECM},{ }^{2} \mathrm{~kg} / \mathrm{d}$ & 32.8 & 32.5 & 0.84 & NS \\
\hline Milk fat, \% & 4.14 & 4.12 & 0.072 & NS \\
\hline Milk protein, \% & 3.42 & 3.42 & 0.043 & NS \\
\hline Milk lactose, \% & 4.91 & 4.94 & 0.028 & NS \\
\hline Milk urea $\mathrm{N}, \mathrm{mg} / \mathrm{dL}$ & 10.2 & 10.0 & 0.61 & NS \\
\hline Milk fat, $\mathrm{kg} / \mathrm{d}$ & 1.31 & 1.30 & 0.034 & NS \\
\hline Milk protein, kg/d & 1.07 & 1.08 & 0.029 & NS \\
\hline Milk lactose, kg/d & 1.56 & 1.58 & 0.042 & NS \\
\hline ECM:ME, kg/MJ & 0.131 & 0.139 & 0.003 & $\dagger$ \\
\hline $\mathrm{ECM} / \mathrm{kg}$ of DM, kg/kg & 1.56 & 1.65 & 0.003 & $\dagger$ \\
\hline Milk protein/feed protein, g/g & 0.305 & 0.322 & 0.007 & $\dagger$ \\
\hline
\end{tabular}

\footnotetext{
${ }^{1}$ On the FF1 treatment, the TMR was fed once a day, and on the FF5 treatment, it was fed 5 times a day. NS = not significant.

${ }^{2}$ Calculated according to Sjaunja et al. (1990).

$\dagger P<0.10$.
}

$32.5 \mathrm{~kg} / \mathrm{d}$ on the FF1 and FF5 treatments, respectively. When parities were analyzed separately, no significant difference in ECM yield between treatments was found for primiparous or multiparous cows. However, the increased feed intake of the multiparous cows on the FF1 treatment after the seventh week of lactation also caused a nonsignificant increase in the ECM yield (Figure 2). The average ECM yields of the multiparous cows were 37.1 and $36.1 \mathrm{~kg} / \mathrm{d}$ on the FF1 and FF5 treatments, respectively. The ECM yield of the primiparous cows was $27.1 \mathrm{~kg} / \mathrm{d}$ on the FF1 treatment and $27.4 \mathrm{~kg} / \mathrm{d}$ on the FF5 treatment. Feeding frequency had no effect on milk fat, protein, lactose, or urea content. In the multiparous cows, a significant interaction was found between feeding frequency and week of lactation for milk fat content. This was caused by the higher milk fat content on the FF1 treatment during the first $3 \mathrm{wk}$ of lactation. The feeding frequency had no effect on milk fat or protein yields.

\section{Energy and Protein Conversion and Development of $B W$ and Body Condition}

Because of the lower DMI of the FF5 cows, the energy (ECM:ME) and protein (milk protein:feed protein) conversion tended $(P<0.10)$ to be better on the FF5 treatment compared with the FF1 treatment (Table 3). The BW change of the primiparous and mature cows during the experiment is shown in Figure 3. No difference was observed in the BW of the primiparous cows fed once or 5 times a day. Also, for the multiparous cows, no difference was observed in BW during the first $19 \mathrm{wk}$ of lactation. Instead, during the last experimental weeks, the mature cows on the FF1 treatment gained more weight than the mature cows on the FF5 treat- ment; however, the interaction between lactation week and treatment was not significant. The feeding frequency had no effect on the development of the BCS of the cows during the experiment. At calving the BCS
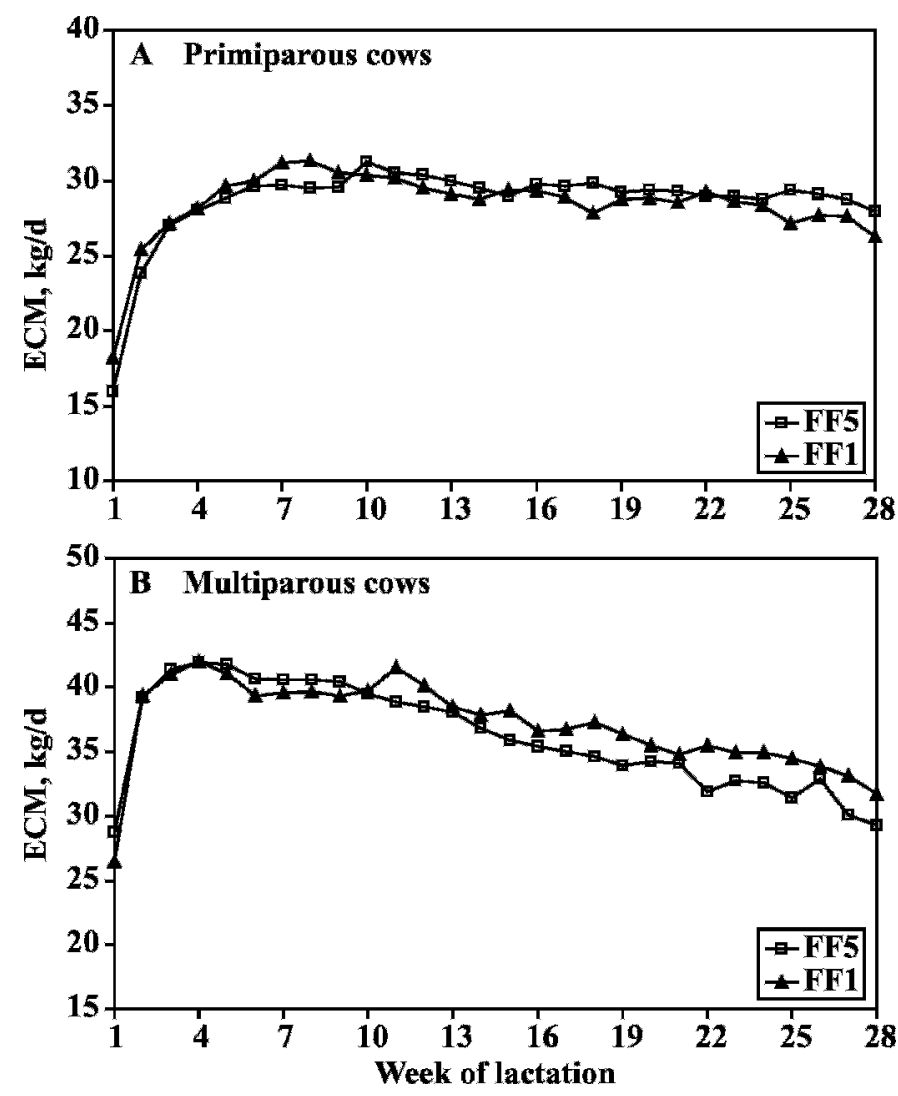

Figure 2. Energy-corrected milk yield of primiparous (A) and multiparous (B) cows fed a TMR once (FF1) or 5 (FF5) times a day. 

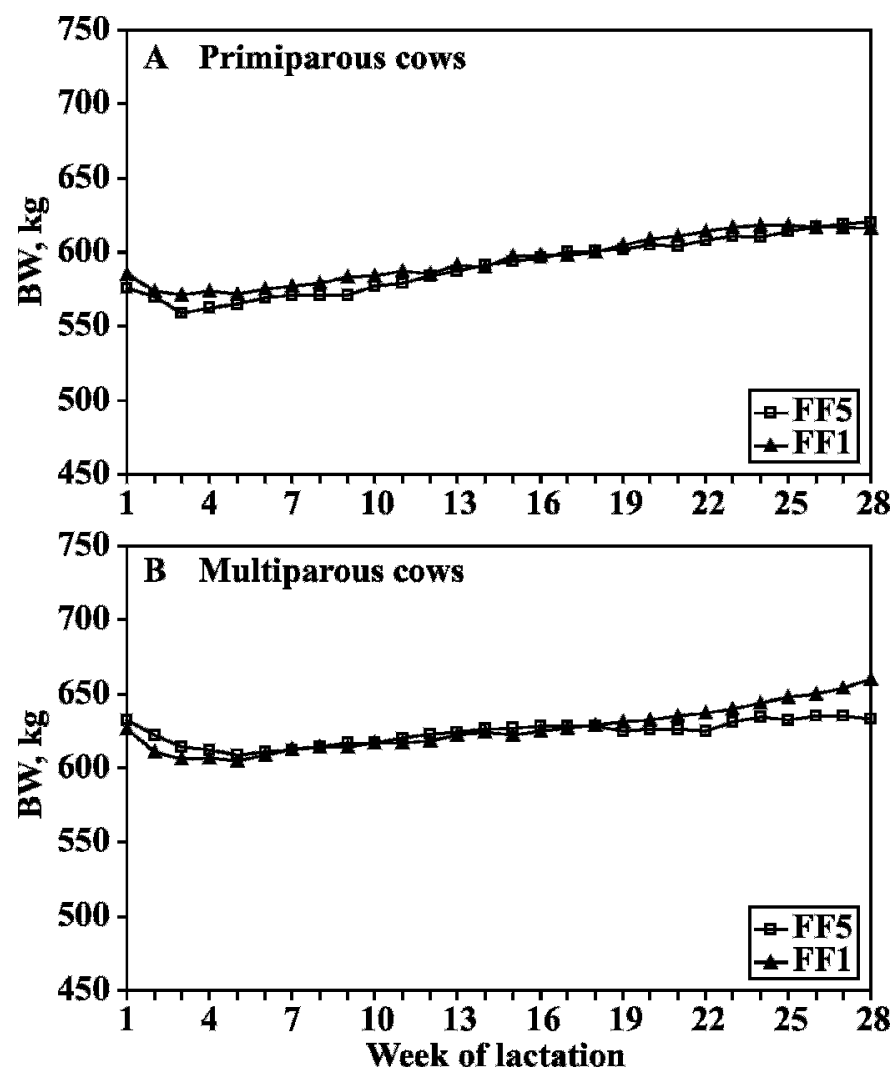

Figure 3. Body weight change of primiparous (A) and multiparous (B) cows fed a TMR once (FF1) or 5 (FF5) times a day.

was 3.1 and 3.0, and at the end of the experiment it was 2.8 and 2.9 on the FF1 and FF5 treatments, respectively. The BCS did not differ among parities.

\section{Feeding Behavior}

During the 15-h observation period, the cows fed 5 times a day spent more time eating than the cows fed once a day (Table 4), although the cows fed once a day consumed more feed. The difference in eating time between the treatments was not statistically significant. The distribution of eating times within the 15$\mathrm{h}$ observation period was in accordance with the feed delivery times (Figure 4). The cows fed 5 times a day tended to eat quite evenly after each delivery. On the FF1 treatment, there were 2 clear peaks in feed consumption in the evening after the feed delivery. The first peak was immediately after allocation of fresh feed at $1630 \mathrm{~h}$, with another one later at $2000 \mathrm{~h}$. There was no difference in standing or ruminating times between the treatments, but the cows fed 5 times a day spent more time ruminating when standing and the cows fed once a day spent more time ruminating when lying (Table 4). Lying not ruminating and total lying times (lying + lying and ruminating) were longer $(P<0.01)$ during the 15-h observation period on the FF1 treatment than on the FF5 treatment (Table 4).

\section{DISCUSSION}

Studies have shown that delivery of feed stimulates the eating activity of cows (DeVries and von Keyserlingk, 2005). Also in our study, an active eating period was noticed following delivery of the feed, and the total eating time was longer $(P>0.05)$ when feed was delivered 5 times compared with once a day. Therefore, one might expect the feed intake to be higher with more frequent feeding. However, in the present study the DMI was greater on the FF1 treatment than on the FF5 treatment. The reasons for the higher intake are not clear. It can be speculated that the larger meal size on the FF1 treatment, compared with the FF5 treatment, might have led feed to be wasted if it were pulled into the stall. However, the fact that the effect of treatment on DMI differed between parities does not confirm this conclusion, nor does the fact that measurable amounts of feed were not seen in the stall. It is likely that the difference in feed intake was associated with the differences in feeding behavior of the cows because of the different feeding frequencies. Phillips and Rind (2001) noticed in their study that cows with a reduced feeding frequency tended to have a higher DMI. This was associated with more relaxed and less aggressive behavior in the feeding passage and increased time spent lying and ruminating. They concluded that the undisturbed feeding situation with reduced feeding frequency gave the cows greater opportunities to select large mouthfuls of TMR. In the present study, we also noticed that the cows on the FF1 treatment spent more time lying than the cows on the FF5 treatment. It is possible that the cows on the FF1 treatment were more peaceful because they were not disturbed so often by feed delivery as the cows on the FF5 treatment. The effect of feeding frequency on feed intake was clearer with multiparous than with primiparous cows. This difference between parities can arise from the differences in milk production and feed intake capacity. High-producing multiparous cows eat large meals more quickly than low-producing primiparous cows (Dado and Allen, 1994).

Contrary to our results, in the studies by Shabi et al. (1999), Le Liboux and Peyraud (1999), and Kudrna et al. (2001), increasing feeding frequency increased the TMR intake. The higher intake was associated with increased feeding time in the study by Shabi et al. (1999), and in the study by Kudrna et al. (2001), the decreased feed intake with less frequent feeding was explained by the high temperature during the summer 
Table 4. Behavior of the cows fed once or 5 times a day ${ }^{1}$

\begin{tabular}{lllll}
\hline $\begin{array}{l}\text { Behavior, percentage } \\
\text { of a 15-h period }^{2}\end{array}$ & $\begin{array}{l}\text { Treatment } \\
\text { FF1 }\end{array}$ & $\begin{array}{l}\text { Treatment } \\
\text { FF5 }\end{array}$ & SEM & Significance \\
\hline Eating & 20.0 & 21.4 & 0.98 & NS \\
Ruminating lying & 23.2 & 21.8 & 1.14 & NS \\
Lying, not ruminating & 24.9 & 20.5 & 1.12 & $* *$ \\
Ruminating standing & 4.0 & 4.8 & 0.63 & NS \\
Standing, not ruminating & 16.5 & 16.8 & 0.84 & NS \\
Total standing & 20.5 & 21.7 & 1.19 & NS \\
Total lying & 48.1 & 42.2 & 1.49 & $* *$ \\
\hline
\end{tabular}

${ }^{1}$ On the FF1 treatment, the TMR was fed once a day, and on the FF5 treatment, it was fed 5 times a day. $\mathrm{NS}=$ not significant.

${ }^{2}$ The observation period was $15 \mathrm{~h} / \mathrm{d}$ between 0600 and $2100 \mathrm{~h}$.

$* * P<0.01$

season and a different level of secondary fermentation of the bunk feeds (Kudrna, 2003). Our study was conducted during the winter season, and we noticed no secondary fermentation of the TMR offered once a day. In agreement with our results, Phillips and Rind (2001), Nocek and Braund (1985), and Dhiman et al. (2002) also reported a tendency to have a higher DMI with lower feeding frequency, whereas no effect of feeding frequency on the DMI of the TMR was observed by Robinson and Sniffen (1985), Shabi et al. (1999), and Kudrna (2003).
In the study by Phillips and Rind (2001), the increased feed intake with lower feeding frequency was associated with increased milk production. In the present study, the increased feed intake of the cows on the FF1 treatment did not cause any increase in milk or ECM production. It is possible that with once-a-day feeding, the larger meal size and changes in the ruminal fermentation affected the digestibility of the diet. Dhiman et al. (2002) and Shabi et al. (1999) showed that the digestibility of DM and NDF decreased with less frequent feeding. Dhiman et al. (2002) found a 19\%

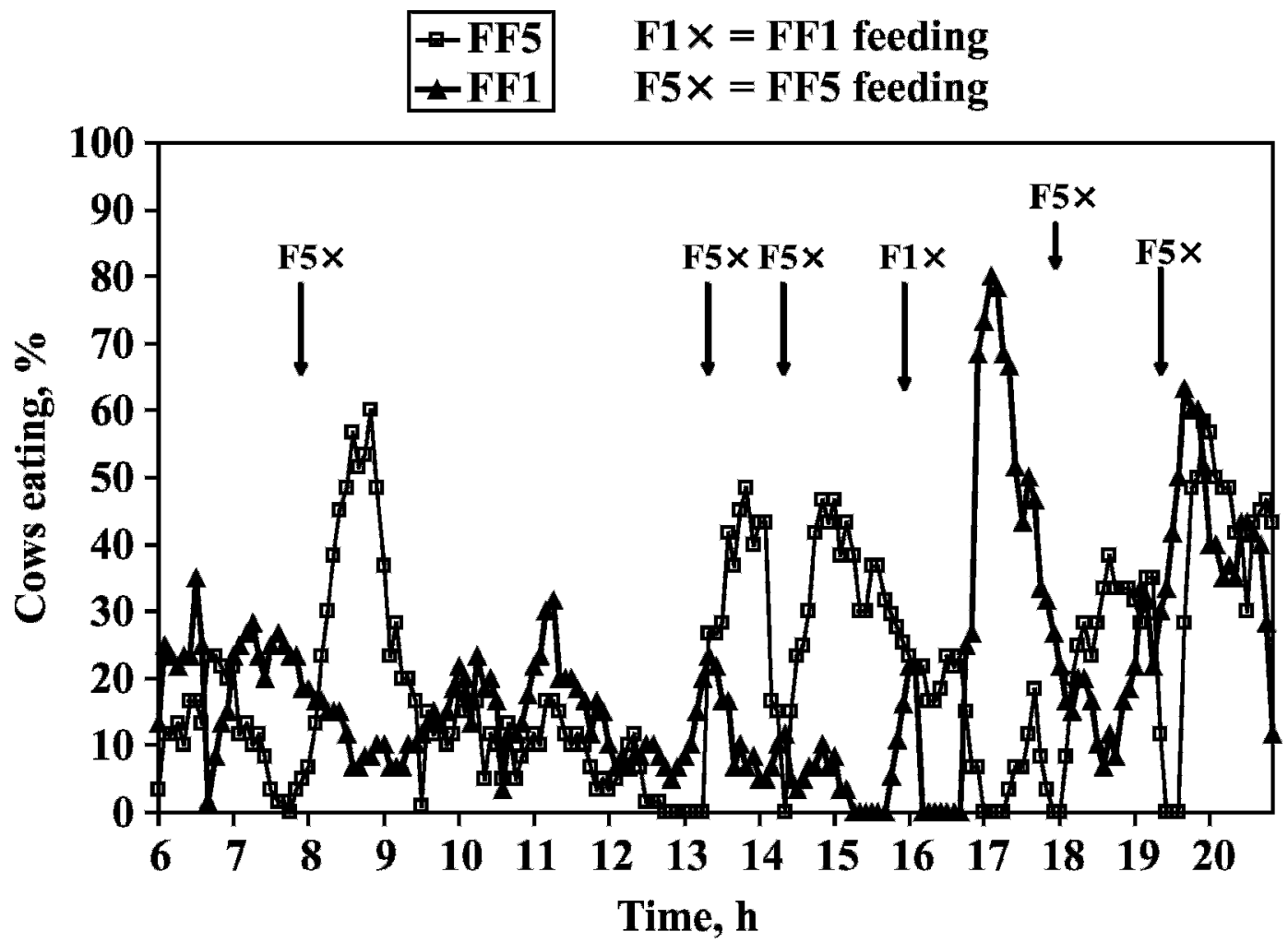

Figure 4. Feeding behavior of cows fed a TMR once (FF1) or 5 (FF5) times a day. On the FF1 treatment, milking took place at 0630 and $1600 \mathrm{~h}$, and on the FF5 treatment milking took place at 0730 and $1645 \mathrm{~h}$. 
decrease in NDF digestibility when TMR was fed once a day compared with 4 times a day. In their study, the average ruminal $\mathrm{pH}$ was not affected by the feeding frequency. However, the reduced fiber digestibility with less frequent feeding can be a result of increased diurnal variation in ruminal $\mathrm{pH}$, as measured in the studies by Le Liboux and Peyraud (1999) and Shabi et al. (1999). In the present study, the cows on the FF1 treatment spent more time eating during the evening hours, whereas the distribution of eating time was more even over the course of the day on the FF5 treatment. This could have increased the diurnal variation in ruminal $\mathrm{pH}$ on the FF1 treatment when a highly digestible TMR was fed. Contrary to the results of Dhiman et al. (2002), Robinson and Sniffen (1985) measured no difference in the digestion of NDF components when a TMR was fed once or 4 times a day.

Neither milk fat nor protein content was affected by the feeding frequency. Phillips and Rind (2001) observed an increased milk fat content with lower feeding frequency. This was postulated to be due to more extensive fiber digestion as a result of increased rumination. In the present study, the time spent ruminating did not differ between treatments.

Feed sorting was observed in the study by DeVries et al. (2005) when a TMR was fed once a day. They compared the forage-to-concentrate ratio of the delivered feed and the orts and noticed that sorting of the TMR reduced the quality of the feed during the day, which could decrease the performance of subordinate cows who are afraid to visit the feed bunk at the time of feed delivery. In the present study, every cow had her own feeding place (transponder collars); therefore, the quality of the feed offered was the same for all cows. In theory it is possible that feed sorting of the FF1 treatment could have increased the diurnal variation in ruminal $\mathrm{pH}$.

Because of the differences in feed intake, the energy and protein efficiency in milk production tended to be lower on the FF1 treatment compared with the FF5 treatment in the present study. In agreement with our findings, Nocek and Braund (1985) observed a slightly higher feed efficiency for primiparous cows fed 4 times a day compared with once a day. No difference in BW development between treatments was noticed in the present study. However, the multiparous cows, whose DMI was clearly higher on the FF1 treatment than on the FF5 treatment, also gained slightly more weight after the 19th week of lactation.

\section{CONCLUSIONS}

Feeding a TMR once or 5 times a day had no effect on milk production or milk composition, but cows fed once a day consumed more TMR than cows fed 5 times a day. The higher intake with once-a-day feeding tended to decrease energy and protein conversion. The study was conducted in the winter; therefore, secondary fermentation in the feed bunk with less frequent feeding was not a concern. Based on the observations of feeding behavior, it seems that feeding TMR 5 times a day might be too frequent because of the increased restlessness and decreased lying time of the cows.

\section{ACKNOWLEDGMENTS}

The authors wish to thank the staff of Minkiö Research Farm for their excellent care of the experimental animals and the collection of behavioral data. The study was partly financially supported by the Finnish Ministry of Agriculture and by Pellonpaja Ltd. and Suomen Rehu Ltd.

\section{REFERENCES}

Albright, J. L., and C. W. Arave. 1997. The Behaviour of Cattle. CAB International, Wallingford, UK.

AOAC. 1990. Official Methods of Analysis. 15th ed. AOAC, Arlington, VA.

Dado, R. G., and M. S. Allen. 1994. Variation in and relationships among feeding, chewing, and drinking variables for lactating dairy cows. J. Dairy Sci. 77:132-144.

DeVries, T. J., and M. A. G. von Keyserlingk. 2005. Time of feed delivery affects the feeding and lying patterns of dairy cows. J. Dairy Sci. 88:625-631.

DeVries, T. J., M. A. G. von Keyserlingk, and K. A. Beauchemin. 2005. Frequency of feed delivery affects the behavior of lactating dairy cows. J. Dairy Sci. 88:3553-3562.

Dhiman, T. R., M. S. Zaman, I. S. MacQueen, and R. L. Boman. 2002. Influence of corn processing and frequency of feeding on cow performance. J. Dairy Sci. 85:217-226.

Friedel, K. 1990. Die Schätzung des energetischen Futterwertes von Grobfutter mit Hilfe einer Cellulasemethode. Wissenschaffliche Zeit. Univ. Rostock, N-Reihe 39:78-86.

Gibson, J. P. 1984. The effects of frequency of feeding on milk production of dairy cattle: An analysis of published results. Anim. Prod. 38:181-189.

Grant, R. J., and J. L. Albright. 1995. Feeding behavior and management factors during the transition period in dairy cattle. J. Anim. Sci. 73:2791-2803.

Haacker, K., H. J. Block, and F. Weissbach. 1983. Zur kolorimetrischen Milchsäurebestimmung in Silagen mit $p$-Hydroxydiphenyl. Arch. Tierernaehr. 33:505-512.

Huhtanen, P. J., R. Blauwiekel, and I. Saastamoinen. 1998. Effects of intraruminal infusions of propionate and butyrate with two different protein supplements on milk production and blood metabolites in dairy cows receiving grass silage based diets. J. Sci. Food Agric. 77:213-222.

Huida, L., H. Väätäinen, and M. Lampila. 1986. Comparison of dry matter contents in grass silages as determined by oven drying and gas chromatographic water analysis. Ann. Agric. Fenniae 25:215-230.

Kudrna, V. 2003. Effect of different feeding frequency employing total mixed ration (TMR) on dry matter intake and milk yield in dairy cows during the winter. Acta Vet. (Brno) 72:533-539.

Kudrna, V., P. Lang, and P. Mlazovska. 2001. Frequency of feeding with TMR in dairy cows in summer season. Czech. J. Anim. Sci. 46:313-319.

Le Liboux, S., and J. L. Peyraud. 1999. Effect of forage particle size and feeding frequency on fermentation patterns and sites and 
extent of digestion in dairy cows fed mixed diets. Anim. Feed Sci. Technol. 76:297-319.

Littell, R. C., G. A. Milliken, W. W. Stoup, and R. D. Wolfinger. 1996. SAS Systems for Mixed Models. SAS Inst. Inc., Cary, NC.

Lowman, B. G., N. A. Scott, and S. H. Somerville. 1976. Condition scoring of cattle. In The East of Scotland Coll. Agric. Bull. No. 6, Edinburgh, UK. 31 pp.

MAFF (Ministry of Agriculture, Fisheries and Food). 1975. Energy allowances and feeding systems for ruminants. In Ministry of Agriculture Fisheries and Food Technical Bulletin No. 33. Ministry of Agriculture, Fisheries and Food, London, UK. 79 pp.

MAFF (Ministry of Agriculture, Fisheries and Food). 1984. Energy allowances and feeding systems for ruminants. In ADAS Reference Book No. 433. Ministry of Agriculture, Fisheries and Food, London, UK. 85 pp.

McCleary, B. V., V. Solah, and T. S. Gibson. 1994. Quantitative measurement of total starch in cereal flours and products. J. Cereal Sci. 20:51-58.

McCullough, H. 1967. The determination of ammonia in whole blood by direct colorimetric method. Clin. Chem. Acta 17:297-304.

MTT. 2004. MTT 2004 Rehutaulukot ja ruokintasuositukset. http:// www.agronet.fi/rehutaulukot/ Accessed June 30, 2004.
Nocek, J. E., and D. G. Braund. 1985. Effect of feeding frequency on diurnal dry matter and water consumption, liquid dilution rate, and milk yield in first lactation. J. Dairy Sci. 68:2238-2247.

Phillips, C. J. C., and M. I. Rind. 2001. The effects of frequency of feeding a total mixed ration on the production and behavior of dairy cows. J. Dairy Sci. 84:1979-1987.

Robinson, P. H., and C. J. Sniffen. 1985. Forestomach and whole tract digestibility for lactating dairy cows as influenced by feeding frequency. J. Dairy Sci. 68:857-867.

Shabi, Z., I. Bruckental, S. Zamwell, H. Tagari, and A. Arieli. 1999. Effects of extrusion of grain and feeding frequency on rumen fermentation, nutrient digestibility, and milk yield and composition in dairy cows. J. Dairy Sci. 82:1252-1260.

Sjaunja, L. O., L. Baevre, L. Junkkarinen, J. Pedersen, and J. Setälä 1990. A Nordic proposal for an energy corrected milk (ECM) formula. Pages 156-157 in Proc. 27th session of the International Committee of Recording and Productivity of Milk Animals, Paris, France, July 2-9, 1990. EAAP Publication No. 50. European Association for Animal Production, Rome, Italy.

Somogyi, M. 1945. A new reagent for the determination of sugars. J. Biol. Chem. 160:61-68.

Van Soest, P. J., J. B. Robertson, and B. A. Lewis. 1991. Methods for dietary fiber, neutral detergent fiber and nonstarch polysaccharides in relation to animal nutrition. J. Dairy Sci. 74:35833597. 